\title{
Small Bowel Adenocarcinoma Presenting with Brain Metastasis
}

\section{Beyin Metastazı ile Başvuran İnce Barsak Adenokarsinomu}

\author{
๑i Isra Al Jorani, ๑ Özgen Işık \\ Uludağ University Faculty of Medicine, Department of Surgery, Bursa, Turkey
}

\begin{abstract}
IIIIIIII| ABSTRACT
Although the small bowel (SB) comprises majority of the length of alimentary tract and its surface mucosal area, adenocarcinoma of SB is rare in comparison to other gastrointestinal malignancies. The most common presenting symptom is intermittent and crampy abdominal pain. Because of the rarity of these lesions and the non-specific and variable nature of the presenting symptoms, delay in diagnosis is common. In this article, we have presented a case of adenocarcinoma of the jejunum with only neurologic symptoms due to brain metastasis.
\end{abstract}

Keywords: Adenocarcinoma, brain metastasis, cancer, small bowel

\section{|IIIIIII| ÖZ}

Her ne kadar ince barsaklar gastrointestinal (Gi) traktın uzunluk ve mukozal yüzey alanı olarak çoğunluğunu oluşturuyor olsa da ince barsak adenokarsinomu diğer Gİ malignitelere oranla çok nadirdir. En sık başvuru nedeni kramp şeklinde aralıklı karın ağıısıdır. Bu hastalığın nadir olması ve başvuru semptomlarının nonspesifik ve değişken olması tanıda gecikmeye neden olmaktadır. Bu makalede beyin metastazına bağlı sadece nörolojik semptomlar ile başvuran bir jejunal adenokarsinom olgusunu sunuyoruz.

Anahtar Kelimeler: Adenokarsinomu, beyin metastazı, kanser, ince barsak

\section{Introduction}

Cancer of the small bowel (SB) represents around less than $2 \%$ of all gastrointestinal (GI) malignancies. The frequency of adenocarcinoma of the SB is about $40 \%$ in all SB tumours. Adenocarcinoma of SB is mostly present in the duodenum followed by jejunum and ileum. ${ }^{1}$ Because of its rare occurrence, nonspecific clinical features of presentation and difficulty of imaging the SB, the disease is usually advanced with either regional or distant metastasis at the time of diagnosis. Brain metastases were identified in less than $4 \%$ of all GI tumours. Although early treatment is associated with prolonged survival and improved outcomes, brain metastasis reflects a late presentation of GI cancers and remains an unpromising situation.

\section{Case Report}

A 67-year-old man with history of diabetes mellitus, hypertension, hyperlipidaemia and disease of the coronary arteries and placement of stent at 3 years ago was presented with the complaint of speech impairment and vertigo. He did not show any symptoms of GI disease, and there was no weight loss. No history of haematemesis or melaena was found in the patient. The patient underwent a cranial magnetic resonance imaging that showed intracranial mass in the frontal lobe (Figure 1). Thus, the patient underwent a surgical resection of the metastasis by craniotomy. Postoperative recovery was uneventful. Histopathology of the specimen revealed metastatic adenocarcinoma; immunohistochemical staining results were consistent with GI system carcinoma. 
The patient was then undergone colonoscopy and upper GI endoscopy without any abnormalities. Abdominal computed tomography (CT) scan showed a 10-mm serosal hyperdense nodule in the medial section of the splenic flexure that was reported as possible subserosal haemorrhage or calcific granuloma (Figure 2). Positron emission tomography CT (PET-CT) scan showed a hypermetabolic involvement in the left lower quadrant of the abdomen of $41 \times 38 \mathrm{~mm}$ in diameter with metabolic activity $\left(\mathrm{SUV}_{\max }: 8.3\right)$.

The patient underwent an exploratory laparotomy based on the results of CT and PET-CT scan with a high suspicion of the presence of small intestinal malignancy. A jejunal mass was seen covered by the greater omentum just inferior to the splenic flexure without any dilatation of the proximal bowel loops (Figure 3). Jejunal segmental resection with lymphadenectomy of the involved segment was done. Postoperative recovery was uneventful. The patient was discharged on postoperative day 3 .

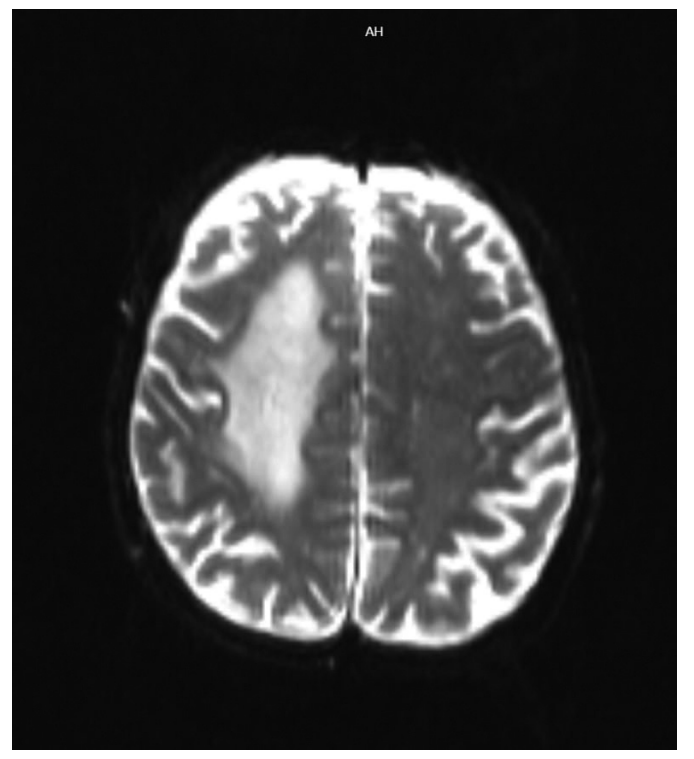

Figure 1. Cranial magnetic resonance image showing intracranial mass

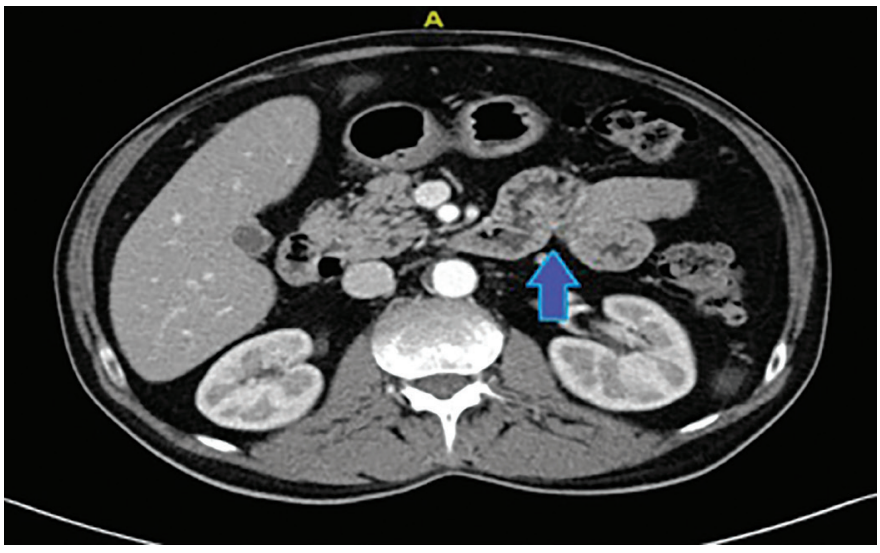

Figure 2. Abdominal computerised tomography images showing the primary tumour
Histopathology of the specimen revealed adenocarcinoma of the small intestine. The proximal and distal resection margins were clear of tumour cells with the presence of three metastatic lymph node involvements. T3N2M1 was the pathological stage of the lesion. The patient was referred to an oncologist for adjuvant chemotherapy. However, the patient was died on postoperative month 8 because of recurrent cranial metastasis.

\section{Discussion}

SB adenocarcinomas are rare, and metastatic disease is associated with poor prognosis. There are limited reported cases in the literature on SB adenocarcinoma presenting with neurologic symptoms due to brain metastasis. In this report, we presented the case of a patient diagnosed with SB adenocarcinoma after surgical removal of intracranial mass. SB adenocarcinomas have poor prognosis. Expected 5-year survival rate is less than $30 \%$. Almost one-third of patients have distant metastasis, and one-third have lymphatic metastasis at the time of diagnosis. Upper GI endoscopy and colonoscopy should be performed to visualise proximal and distal SB tumours and also to clarify underlying diseases such as inflammatory bowel disease. Clinical staging can be done with chest-abdomen-pelvis CT scan. SB resection is performed with necessary lymphatic dissection. Surgery alone may be curative for stages I and II of the disease, while adjuvant chemotherapy is necessary for stages III and IV patients. Currently, surgical treatment is the only curative option for stages I and II. Fluoropyrimidine and platinum combination may be considered in systemic therapy. ${ }^{2}$ Our patient underwent SB resection with lymphadenectomy, and the final pathology revealed stage T3N2 of the disease.

Most common sites of metastasis for SB adenocarcinomas are lymph nodes, liver and peritoneum. ${ }^{3}$ Incidence of brain metastasising SB adenocarcinoma is unclear due to its rarity. Reported survival is median 10 (range: 3-28) months. ${ }^{4}$ Surgical removal, and/or whole brain radiotherapy, is the

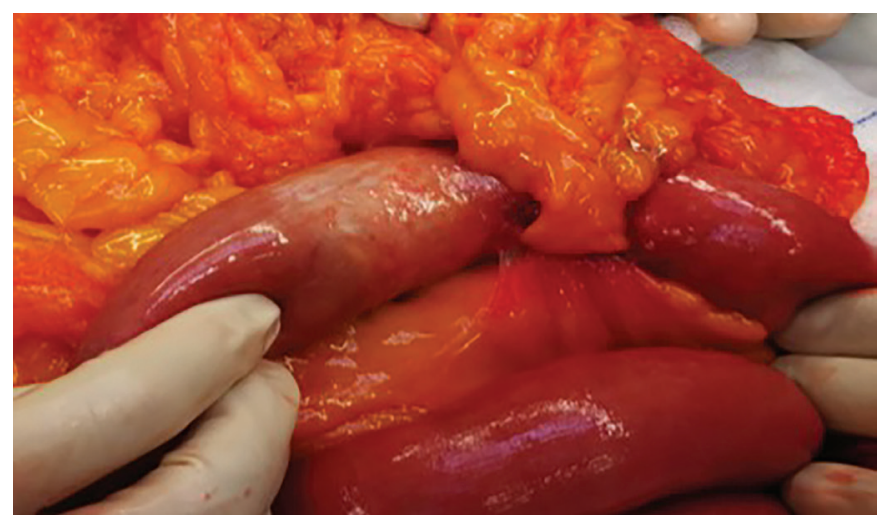

Figure 3. Intraoperative image of the primary tumour covered by omentum 
most preferred treatment of choice for brain metastasis of SB adenocarcinomas. ${ }^{5}$ As the primary tumour was asymptomatic, our patient had to undergo upfront cranial mass removal. He received adjuvant whole brain radiotherapy after small bowel resection surgery.

In conclusion, SB adenocarcinomas are rare cause of GI malignancies. Resection with local lymphadenectomy is the procedure of choice for local disease. However, distant metastases exist at the time of diagnosis in one-third of patients. Metastatic disease has poor survival, even curative resection of the primary tumours and metastases can be achieved.

\section{Ethics}

Informed Consent: Patient's informed consent was obtained. Peer-review: Internally and externally peer reviewed.

\section{Authorship Contributions}

Surgical and Medical Practices: I.A.J., Ö.I., Concept: Ö.I., Design: Ö.I., Data Collection or Processing: I.A.J., Ö.I., Analysis or Interpretation: I.A.J., Ö.I., Literature Search: I.A.J., Ö.I., Writing: I.A.J., Ö.I.
Conflict of Interest: No conflict of interest was declared by the authors.

Financial Disclosure: The authors declared that this study received no financial support.

\section{References}

1. Aparicio T, Zaanan A, Svrcek M, Laurent-Puig P, Carrere N, Manfredi S, Locher C, Afchain P. Small bowel adenocarcinoma: Epidemiology, risk factors, diagnosis and treatment. Dig Liver Dis 2014;46:97-104.

2. Locher C, Batumona B, Afchain P, Carrère N, Samalin E, Cellier C, Aparicio T, Becouarn Y, Bedenne L, Michel P, Parc Y, Pocard M, Chibaudel B, Bouché O; Thésaurus National de Cancérologie Digestive (TNCD). Small bowel adenocarcinoma: French intergroup clinical practice guidelines for diagnosis, treatments and follow-up (SNFGE, FFCD, GERCOR, UNICANCER, SFCD, SFED, SFRO). Dig Liver Dis 2018;50:15-19.

3. Yamazawa E, Honma Y, Satomi K, Taniguchi H, Takahashi M, Yoshida A, Tominaga K, Miyakita Y, Ohno M, Asanome T, Satomi N, Narita Y. A rare case of brain metastasis from poorly differentiated small bowel adenocarcinoma. Surg Neurology Int 2019;10:256.

4. Salvati M, Cervoni L, Paolini S, Delfini R. Solitary cerebral metastases from intestinal carcinoma. Acta Neurochir (Wien) 1995;133:181-183.

5. Go PH, Klaassen Z, Meadows MC, Chamberlain RS. Gastrointestinal cancer and brain metastasis: a rare and ominous sing. Cancer 2011;117:36303640 . 